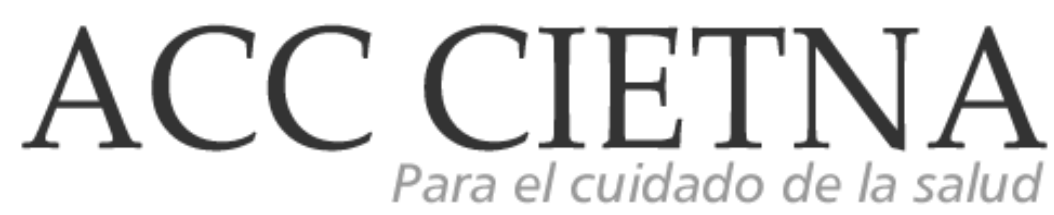

https://doi.org/10.35383/cietna.v3i1.50

EDITORIAL

\title{
Infundir ganas de vivir y salvar la soledad
}

\section{Cervera Vallejos Mirtha Flor ${ }^{1}$}

\section{INFORMACIÓN DEL ARTÍCULO}

Historia del artículo:

Recibido el 23 de enero de 2016

Aceptado el 15 de marzo de 2016

\section{Palabras claves:}

Enfermería

Cuidado

Soledad

\section{RESUMEN}

A causa de nuestra profesión estamos permanentemente en contacto con poblaciones de diversas latitudes, de diversas religiones, también participamos activamente con las diferentes instituciones sanitarias, como la familia y la comunidad, porque somos profesionales próximos a la acción dentro de las poblaciones y que partiendo de los interlocutores, aportamos una contribución específica y concreta para la promoción de la salud y para una mejor calidad de vida.

Los enfermeros tienen la inmediatez y la cercanía, si así, lo deciden de estar junto al enfermo las veinticuatro horas del día, todos ellos están delante de sus ojos; y son a quienes los enfermos, les confían su dolor, preocupaciones problemas y quejas, como vertiente donde desembocan todo tipo de experiencias vividas y que saltan hacia fuera cuando permanecen en cama.

Entonces la enfermera (o) docta, hábil en manejar su ciencia descubre que en medio de esa queja y variedad de expresiones existe el deseo de no vivir de abandonarse a lo que venga, de esperar incluso la muerte. Sin embargo, el contacto con el enfermo, el acercamiento, mirar con presencia cuidadora y delicadeza extrema le permite descubrir las fortalezas y potencialidades, que quizá el mismo enfermo desconoce poseer y con su palabra oportuna le abre horizontes con visión amplia de la propia vida y de los que están a su alrededor.

Por ello, tiene que infundirle ganas de vivir siempre, de superar el dolor, tales como : el sufrimiento causado por la enfermedad o dar a los problemas que cursa el sitio que les corresponde, otra forma es ayudando a encontrar sentido al propio sufrimiento y seguir viviendo bien, motivándole a tomar decisiones sencillas como aceptar el tratamiento, guardar la dieta, dejar las preocupaciones mientras están

\footnotetext{
${ }^{1}$ Doctora en Enfermería. Docente en la Escuela de Enfermería de la Universidad Católica Santo Toribio de Mogrovejo, Chiclayo, Perú.

Email: mcervera@usat.edu.pe ORCID: https://orcid.org/0000-0002-4972-1787
} 
hospitalizados; de tal manera que su estancia hospitalaria sea una aventura donde el protagonista es él, capaz de tomar decisiones y de crecer en medio de la enfermedad anclado en la fe que profesa.

Cuando la enfermera tiene un sólido sentido del valor de la vida y una profunda concepción de la muerte, acompañará de acuerdo a sus circunstancias profesionales a la persona durante todo este ciclo, su presencia cuidadora tiene que mostrarse en el transcurso de la enfermedad, durante las guardias, ante el llamado concreto, en las actividades procedimentales, cuando el estado de conciencia del enfermo no le permita darse cuenta quien lo está cuidando o cuando la persona ya no es un sujeto de derecho, sino objeto de derecho porque aconteció el fallecimiento, acompañando a la familia para vencer el temor y el miedo por la muerte.

Nunca el enfermo se debe sentir solo, es importante hacer el esfuerzo necesario para darle ratos de compañía, de contacto terapéutico, que sienta en todo momento la presencia física, la sonrisa alentadora, la mirada comprensiva, cogerle la mano para trasmitirle calma, su soledad está superada por la presencia impecable de su enfermera.

Al respecto, una mujer adulta mayor llama insistentemente a la enfermera, esta se acerca y le pregunta ¿Qué desea? y la mujer le dice con énfasis en la voz, iquiero que me dé un abrazo! y la enfermera se lo da y se retira. Luego la enfermera razona del porque la paciente le pidió un abrazo, entonces regresa y le pregunta a la señora ¿por qué me pidió un abrazo? Y ella responde con una cara feliz, porque hoy es mi cumpleaños y mi madre me solía dar un abrazo muy fuerte cómo el que Ud. me acaba de dar, muchas gracias...

Los enfermeros, ahogamos la soledad del otro cuando somos acogedores, hospitalarios, cuando pensamos más en aliviar que en ser aliviadas, cuando sabemos sonreír aunque no nos sonrían, cuando amamos y rezamos en silencio aunque nadie se acuerde de nosotros, porque la recompensa futura será mayor y la felicidad perdurará por siempre al ser acogidas al final de la VIDA por el gran Amor.

\section{INFUNDER WINS TO LIVE AND SAVE SOLITUDE}

\section{ABSTRACT}

Keywords:

Nurse

Care

Loneliness
Because of our profession we are permanently in contact with populations from different latitudes, from different religions, we also actively participate with the different health institutions, such as the family and the community, because we are professionals close to the action within the populations and starting from The partners, we make a specific and concrete contribution to the promotion of health and to a better quality of life.

The nurses have the immediacy and closeness, if so, they decide to be with the patient 24 hours a day, they are all in front of their eyes; And they are the ones who are entrusted with their pain, worries problems 
and complaints, as a slope where all sorts of experiences come to fruition and that jump out when they remain in bed.

Then the learned nurse, skilled in handling her science, discovers that in the midst of that complaint and variety of expressions there is a desire not to live to abandon herself to what comes, to even expect death. However, contact with the patient, the approach, looking with caring presence and extreme delicacy allows him to discover the strengths and potentialities, which perhaps the same patient does not know and with his timely word opens horizons with a broad vision of his own life and Of those around you.

Therefore, it has to infuse you with the desire to live always, to overcome the pain, such as: the suffering caused by the disease or to give to the problems that the site that corresponds to them, another way is helping to find meaning to the own suffering and to follow Living well, motivating them to make simple decisions such as accepting treatment, keeping their diet, leaving worries while hospitalized; So that his hospital stay is an adventure where the protagonist is he, able to make decisions and grow in the midst of illness anchored in the faith he professes. When the nurse has a strong sense of the value of life and a profound conception of death, she will accompany the person according to his / her professional circumstances during this whole cycle, his / her caregiving presence must be shown in the course of illness, Guards, before the concrete call, in procedural activities, when the patient's state of consciousness does not allow him to realize who is caring for him or when the person is no longer a subject of law, but an object of law because death occurred, accompanying To the family to overcome fear and fear of death.The patient should never feel alone, it is important to make the necessary effort to give him time of companionship, of therapeutic contact, who feels at all times the physical presence, the encouraging smile, the sympathetic gaze, take his hand to convey calmness, his solitude Is overcome by the impecable presence of her nurse. In this regard, an older adult woman calls insistently to the nurse, she approaches and asks what she wants? And the woman says with an emphasis on the voice, I want you to give me a hug! And the nurse gives it to her and leaves. Then the nurse reasons why the patient asked her for a hug, then comes back and asks the lady why she asked me for a hug? And she responds with a happy face, because today is my birthday and my mother used to give me a very strong hug like the one you just gave me, thank you very much ...

Nurses, we drown the loneliness of the other when we are welcoming, hospitable, when we think more of alleviating than of being relieved, when we know how to smile, even if they do not smile at us, when we love and pray in silence even though no one remembers us, Greater and happiness will endure forever to be welcomed at the end of LIFE by the great Love. 